\title{
幼児の共同作業場面における発話行動
}

\author{
柴田利男 \\ (北星学園大学 社会福祉学部 福祉心理学科) \\ Key words: 発話行動，共同作業，幼児
}

目的

本研究では, 幼児の仲間との共同作業中にみられる発話に 関して, 発話量や発話内容を分析し, その発達的变化につい て検討する。

また共同作業課題の達成度と評価，およびパートナーとの 親密度についても, 発話量也発話内容との関連性を検討する。

\section{方 法}

刘象者 札幌市内の $\mathrm{S}$ 幼稚園の年長クラス 20 名（5～6 歳 児, 男児 10 名·女児 10 名), 年中クラス 20 名 (4 5 歳児, 男児 10 名・女児 10 名）の計 40 名を対象とした。

実験材料 市販の幼児用ジグソーパズル（タイトルは「う みべで大さわぎ」 40 ピース）を使用した。またビデオカメラ と指向性ステレオマイクロホンを用いて幼児の行動と会話を 撮影した。

手続き 幼稚園の 1 室を実験室として使用した。幼児 2 人 用サイズのテーブルの片側に椅子を 2 つ並べ，反刘側には被 験児の上半身が映るくらいの位置に, マイク付きビデオカメ ラを三脚で固定した。ヒントシート（完成図）は被験児に見 えるようビデオカメラの下に貼った。また，パズル課題後の 質問の際, 実験者と被験児が個別に対話できるように, テー ブルと椅子をもう 1 組用意した。

予備実験に基づき, 年長児と年中児で課題条件を変更した。 年長クラス:パズルを均等に 20 ピースづつ分け, 被験児か ら見て絵柄が正面になるように向きを揃えてテーブルの両端 に配置し, 真ん中にパズルを組み立てるスペースを作った。

年中クラス:外枠を除くパズルを均等に 9 ピースづつ分け, 被験児から見て絵柄が正面になるように向きを揃えてテーブ ルの両端に配置した。また, 真ん中のスペースには実験者が あらかじめパズルの外枠のみを作っておいた。

実験は同じクラスの「同性の仲良し 2 人ペア」で行った。 実験者は, 2 人で相談しながらパズルを完成させるよう教示 した。撮影は作業開始から 5 分間とした。5 分経ったところ で未完成であった場合, 撮影を止めてから実験者が介入し, 一緒にパズルを完成させた。

課題終了後, 幼児に対して 2 名の実験者が個別に質問を行 った。質問項目は, パズル課題について 5 問（1. パズルは楽 しくできたか？ 2. パズルでよく遊ぶか？ 3. パズルは得 意か苦手か? 4. パズルはうまくできたか?（達成感） 5. パートナーと協力してできたか?) およびパートナーとの関 係 (親密感)について 3 問 (6.パートナーとはよく一緒に遊 ぶか? 7. いつも何をして遊ぶか? 8. パートナーと仲良 しだと思うか?) であった。質問 7 を除き, 回答は 0 ～点で 採点した。

発話データの整理 実験者介入前の 4 分間を対象として, ペアの発話総時間・発話総回数と, 1 人ひとりの発話時間 発話回数を記録した。この際，笑いに伴う発話や歌などの伝 達意思のない発話も本人の発話回数に含めた。なお連続した 発話は, 文章が完結しているか, または内容が変化している か否かで 1 回または複数回と判断した。同じ言葉を連続的に 繰り返し発話した場合は, 1 回とカウントした。

発話内容は, 1 回の発話ごとに, 指示, 提案, 疑問, 推測,
応答, 許可, 感想, 指摘, 注意喚起, 無関係, その他に分類 した。

\section{結果と考察}

発話時間, 発話回数について, 年龃X性別の分散分析を行 つた。その結果, 発話量における発達的な変化はないことが 明らかとなった。しかし, 被験児ごとの笑いに伴う発話回数 については, 女児よりも男児に多い傾向があった。これは, 男児が「楽しい」「おもしろい」などの感情を言語ではなく, 笑いという行動によって表出しているのではないかと考えら れる。一方, 女児はこのような感情であっても言語として表 出していると考えられ, 男児の発話が一部で間接的であると いうことが推測できる。このことは先行研究を支持するもの である。

幼児の発話には, 自己の行為に関する記述的発話つまり独 語が頻繁にみられたが，これに対しもう一方の幼児が発話を もって何らかの反応を示していた場合が多くみられた。よっ て幼児の「ひとりごと」にも他人を意識したコミュニケーシ ヨン機能があるのではないかと考えられる。そして幼児には その「ひとりごと」を伝達意思として受け取り反応を示す場 合があること見出すことができた。

次に発話内容のカテゴリー間の相関関係を検討したところ, 『感想』と『指摘』,『疑問』と『推測』に類似性がみられた。 前者は課題に対する興味也集中度に関連する発話と解釈でき, 日常の遊び場面において自然的に発せられている発話と考え られる。また後者は意味内容に高い類似性があると思われる。

各カテゴリーについて年齢X性別の分散分析を行った結果, 『推測』は男児よりも女児に多く出現することが明らかにな った。このことから, 共同作業場面において, 問題の解決策 として, 発話を思考の重要な道具にしているのは, 男児より も女児に多いと考えられる。

また,『無関係』は年中児に多く『その他』は年長児に多い 傾向があることがわかった。このことは, 他者理解に関連し て年長児の発話内容が高次なものであることを示している。 そして,『無関係』『その他』は相手に発せられたものが多く, パートナーと何らかのコミュニケーションをとろうとする意 図があったのであれば, 年中児は課題とは関係のない他の話 題に関する発話をもって, 一方の年長児では課題に関するよ り高次な発話をもって, お互いの協調をはかっていると言え るかもしれない。

\section{今後の課題}

課題後の質問については, 本研究では回答にばらつきがき わめて小さかったため分析することが出来なかった。

本研究では, 状況を共同作業場面に，また被験児を「同性 の仲良しペア」に特定して実験を行った。しかし, 状況を自 由遊び場面に, または被験児ペアをランダムに組み合わせる などの対照群を用いて同様の研究を行えば，より明確な結果 を見出すことができるだろう。

(SHIBATA Toshio) 